\title{
Dynamic Capabilities Impact on Innovation: Niche Market and Startups
}

\author{
Mosarrat Farhana ${ }^{1 *}$, Daniel Swietlicki ${ }^{1}$
}

\begin{abstract}
The purpose of this study is to understand innovation of startups operating in a niche market. Through a review of previous research works, a conceptual model and propositions are developed, where illustration of a company case is used to exemplify this model. It reveals that a research gap exists regarding startups in a niche market with dynamic capabilities and breakthrough innovations as a source of success. This study reflects on the potential relationship between dynamic capabilities and breakthrough innovation of a startup and its subsequent effect on the performance of the startup in a niche market. It has proposed that dynamic capabilities work as a foundation for startup to develop a breakthrough innovation. It also proposed that in a niche market, both core competency and industrial network are crucial for a startup to scaleup, where breakthrough innovation works as a pathway to acquire consumer acceptance.
\end{abstract}

Keywords: Dynamic capabilities; startup; niche market; breakthrough innovation.

Submitted: August $11^{\text {th }}, 2020 /$ Approved: October $22^{\text {nd }}, 2020$

\section{Introduction}

This paper will be centered around how dynamic capabilities of a startup influence its breakthrough innovation in a niche market considering a case study on the company named Hövding selling innovative airbag bicycle helmet in Europe. A research gap has gradually been identified to conduct the purpose of the study while delimitations have defined boundary this study.

Background. In today's society research and innovation is vital for sustaining a competitive advantage and for the advancement of society. Entrepreneurs and innovation play a significant role behind the growth of global economy (Cruz-Ros, Garzón \& Mas-Tur, 2017; Lewrick, Raeside \& Sailer, 2010). The production, diffusion and use of an economically viable new idea generates competitive advantage for the sustainable growth of any business startup (Lewrick et al., 2010). It is said success does not come from solely improving existing products, but from innovating and coming up with new ones. However, it is not only about creativity and invention but how you commercialize your ideas and realize them, beginning with consumers wants and needs. Entrepreneurial activities pursued by either small startup or large incumbents aim to transform the market and the society, even though pioneering entrepreneurs operating in a niche market find it challenging to influence the masses (Hockerts \& Wüstenhagen, 2010; Schaltegger, Hansen \& Lüdeke-Freund, 2016). In many cases, innovative entrepreneurs or startups in collaboration with regulators and nongovernmental organizations take the front-runner positions to shape-up societal context (Geels \& Schot, 2007). To depict the interplay between innovation and entrepreneurship, Snow (2007) has considered both concepts as virtually the same, as innovation refers to 'the introduction of new product or service'; whereas entrepreneurship refers to 'the founding of a new business'.
According to Peter Drucker (1985)

"Innovation is the specific tool of entrepreneurs, the means by which they exploit an opportunity for a different business or service."

Since the late 1990s the concept of entrepreneurship evolves as a key driver of economic growth of a nation, job creation and innovation, which in turn has made it an interesting arena for academic researchers (Ruiz, Soriano \& Coduras, 2016). As a consequence, different institutes or organizations such as the Global Entrepreneurship Monitor (GEM), the Community Innovation Survey (CIS) by European Union have been developed to measure the performance of startups, any entrepreneurial initiatives and innovation and to accelerate policy development process to reap the best outcomes (Ruiz et al., 2016; Eurostat, 2017).

EU policies are often designed to encourage innovation with numerous surveys conducted by the European Union keep track of these innovative activities of its member states (Eurostat, 2017). Close to half of the member states reported some form of innovation during 2012 and 2014 with countries like Germany, Luxemburg and Belgium having high proportions (above $60 \%$ ) of innovative enterprises (Eurostat, 2017). Almost $25 \%$ average of the enterprises were product innovators during the same period with countries like Finland, Germany and Sweden being over $30 \%$ (Eurostat, 2017). Sweden has been fostering innovation and entrepreneurship through for example government agencies like Vinnova, funding research in different fields such as transport, industrial materials and smart cities ("Sweden", 2019). The European innovation scoreboard analyses the innovative performance of each country and ranked Sweden as number 1 in 2018 with an observed improvement in Europe overall (European innovation scoreboard, 2018). Other agencies in Sweden focus on supporting innovation in universities, funding

(1) School of Business and Economics, Linnaeus University, Sweden.

*Corresponding author: mosarrat_58@yahoo.com

ISSN: 0718-2724. (http://jotmi.org)

Journal of Technology Management \& Innovation ( ) Universidad Alberto Hurtado, Facultad de Economía y Negocios. 
research and competence development ("Sweden", 2019). Here aspiring entrepreneurs can connect and share ideas as breakthrough innovation requires a diversity of knowledge (Schoenmakers \& Duysters, 2010). A problem facing some startups is the lack of external cooperation and exchange of ideas sometimes leading entrepreneurs to move forward without necessary input (Schoenmakers \& Duysters, 2010). On that ground business plan competition named 'Venture Cup' in collaboration with universities and business school in Northern Europe works a great platform for young entrepreneurs and startups to gain entrepreneurial knowledge and start their own businesses (Maack, Klofsten \& Hedner, 2011). Academic researchers (Maack et al., 2011) have figured out that since its launch in 1998 in Gothenburg in Western Sweden, more than 10,000 unique business ideas are submitted among which a good number of startups are now operating nationally and internationally such as Applied Nano Surfaces,Nanologica, Bambusa, Hövding and many more.

Problem discussion. Based on the innovation capabilities of a firm, the degree of innovation varies from completely new to minor upgradation (Garcia \& Calantone, 2002; Cheng \& Chen, 2013), and this can be categorized as either breakthrough innovation or incremental innovation (Johannessen, Olsen \& Lumpkin, 2001; O’Connor \& De Martino, 2006; Song \& Di Benedetto, 2008). While incremental innovations result in minor or simple improvement or line extension of a product, breakthrough innovations offer greater customer benefits and new consumption pattern in comparison to existing product through new technology (O'Connor \& De Martino, 2006; De Visser et al., 2010; Cheng \& Chen, 2013). Though the complex nature of the breakthrough innovation reflects firm's 'hard-to-imitate' and 'hard-to-transfer' skills and ability, ultimately success largely depends upon firm's ability to commercialize it (Rogers, 2003; Zollo \& Winter, 2002; Cheng \& Chen, 2013).

"First mover advantage doesn't go to the first company that launches, it goes to the firstcompany that scales."

Reid Hoffman, co-founder of LinkedIn (“ScaleIt”, 2018)

Though entrepreneurship brings out new organizations with new creations or innovations exploiting opportunities in the market, entrepreneurs have to consider other hard sides of this total process such as risk taking approach, proactivity and capacity to utilize innovation (Ruiz et al., 2016). Since today's marketplace is very user-defined, a great invention might not satisfy the consumer' need rather than turning into a technological breakthrough (Gallagher, 2011). Young entrepreneurs are keen to take risk and come up with their revolutionary ideas, but in many cases their startups fail to be scalable or profitable due to lack of financial support and professional skills to survive in a dynamic competitive marketplace (Moroni,Arruda \& Araujo, 2015). For the last few decades, researchers have worked on different dimensions of the entrepreneurship concepts, entrepreneurial values, and its relation with economic growth and innovation (Arenius \& Minniti, 2005; Hessels, Van Gelderen \& Thurik, 2008; Bosma \& Schutjens, 2009; Evald, Klyver \& Christensen, 2011; Ruiz et al., 2016). Even with an aim to learn the practical facts about entrepreneurship, academic researchers have introduced entrepreneurship and innovation programme as part of education system to make new startups more ready for the marketplace (Lewrick et al., 2010). Other researchers have come up with win-win solutions for both big corporate houses and young entrepreneurs such as working in joint venture (Moroni et al., 2015). As creating breakthrough innovation is very difficult, it is a great option for corporates to source innovative product or service. But for independent entrepreneurs systematic education is not enough to launch a startup and make it sustainable for the long term, especially when it is a breakthrough innovation targeting niche market (Lewrick et al., 2010). The success of any type of innovation largely depends on firm's ability and efficiency in exploration and exploitation of its dynamic capabilities irrespective of the size of the firm (AarikkaStenroos, Sandberg \& Lehtimäki, 2014). In the field of innovation and entrepreneurship, most of the research works have focused on entrepreneurial orientation and activities within any corporation to accelerate innovation process. However, research on impact of dynamic capabilities on startup's breakthrough innovation and its performance in a niche market is yet to be explored at the fullest with some empirical studies (Moroni et al., 2015). On that ground, authors of this paper intend to pursue this study to contribute in this potential field of study. This conceptual paper intends to contribute to the growing knowledge in the field of innovation and entrepreneurship and to present a research gap for the academic researchers to pursue further empirical research. Moreover, it will give valuable insights to practitioners or organization working to support young startup.

Purpose and delimitations. The purpose of this study is to understand innovation of startups operating in a niche market.

This study has been carried out within the context of new startup and its breakthrough innovation and has been limited within the boundary of firm's dynamic capabilities in a niche market. Here, the case of a Swedish company named Hövding has been chosen, which has entered into the market with a very innovative niche product.

Outline of the study. This paper is structured chronologically by presenting a literature review based on existing scholarly works on dynamic capabilities and breakthrough innovation and startups in a niche market. Then it is followed by method section describing how this conceptual research has been carried out. In the content analysis and result part, findings of this study have been analysed based on previous research works. Then, a conceptual model and propositions about relationships in the model are presented along with illustrative company case. Finally, it is concluded with presenting managerial implications, pointing out limitations of this study and scopes for the future researchers in this field.

\section{Key Concepts}

Dynamic capabilities and Breakthrough innovation. Dynamic capabilities are seen as drivers of creation and rearrangement of different resources to create new resources to give the company a competitive advantage (Henderson \& Cockburn, 1994). Eisenhardt \& Martin (2000) defines dynamic capabilities as: 
The firm's processes that use resources-specifically the processes to integrate, reconfigure, gain and release resources-to match and even create market change. Dynamic capabilities thus are the organizational and strategic routines by which firms achieve new resource configurations as markets emerge, collide, split, evolve, and die. (p. 1107)

Many studies have been conducted on dynamic capabilities and most researchers agree that these can increase a company's competitive advantage (Wu, 2007). They are generally viewed as a transformer that creates improved performance out of existing resources. Deeds, DeCarolis \& Coombs (2000) suggest that technology heavy firms should take advantage of their dynamic capabilities to innovate and produce new products as a way of not falling behind in a fast pace industry. Dynamic capabilities are seen as vague by some but in reality exist of specific routines studied by many (Eisenhardt \& Martin, 2000). One example is product development routines where managers work together contributing with different skills to create new products and services (Helfat \& Raubitschek, 2000). If a company wants to improve their breakthrough innovations researchers suggest investing in dynamic innovation capabilities that can produce exciting new products (Davenport, Leibold \& Voelpel, 2006; Teece, 2007). Some are still in disagreement regarding whether dynamic capabilities can lead to breakthrough innovation while some suggest that they will foster innovation (Antikainen \& Väätäjä, 2010). Researchers claim a company investing in dynamic capabilities will be more attuned to absorb and explore new information to cultivate breakthrough innovation (Lavie \& Rosenkopf, 2006). Firms collecting information and becoming more proficient using their existing knowledge which can lead to more incremental innovation and not the desired breakthrough (Benner \& Tushman, 2003).

The level of innovation can vary hence the categorization incremental and breakthrough innovation (Song \& De Benedetto, 2008). With incremental signifying minor changes to technology while breakthrough innovation involves considerably new technology (De Visser et al., 2010). Researchers also use the term radical innovation synonymously with breakthrough innovation as they both signify significant innovation (Kusunoki, 1997). These new innovations often lead to greater levels of complexity and may require the acquisition and development of new knowledge and innovation capabilities (Song \& De Benedetto, 2008). Researcher have suggested the development of dynamic innovation capabilities can boost breakthrough innovation in companies but can also have some drawbacks (Cheng \& Chen, 2013). In Cheng and Chen's study (2013) they found that having these capabilities could even prevent the desired breakthroughs. Companies run the risk of becoming rooted the longer they have innovation capabilities and might miss changes in their environment.

Startups in niche market. According to Eric Ries (2011) a startup can be defined as "a company or a human institution that is built on different branches and that spontaneously arises the condition of extreme uncertainty, has at its core innovation to create products and services which they wish revolutionize the market." Theoretically the concept of startup evolves around any product or service innovation and the risk taking capability of young entrepreneurs (Blank \& Dorf, 2012). Young entrepreneurs or startups play significant role in the economy of a country through their revolutionary and disruptive ideas, and financial performance (Moroni et al., 2015). According to Moroni et al. (2015), in the XXI century, though young firms known as startups prefer to enter into a niche market with a perception of highly profitable market and fast consumer acceptance due to the innovativeness of the product or service, the actual success rate is still questionable. Researchers have also argued that innovation is not enough to make startups stable, profitable and sustainable in a fiercely competitive market (Moroni et al., 2015). As startups operate in rapidly changing dynamic environments with greater risk and uncertainty, researchers agreed that traditional mechanism of management barely works for young startups (Ries, 2011; Moroni et al., 2015). Moreover, in today's user-defined marketplace, it is crucial for startups to interpret their external environment properly and link that with their internal strength for sustainable competitive advantage (Moroni et al., 2015), otherwise their offering could be a simple representation of technological breakthrough in a niche market (Gallagher, 2011).

Referring to the concept of niche, Kevin Gallagher (2011, p.46) has stated as - "Sometimes a new niche starts with an analysis of the market and other times it begins with a technological breakthrough that leads us to help define a new performance claim that we believe will resonate with consumers." Though for the last few decades researchers and practitioners have emphasized the concept of 'niche market' or 'niche marketing' as a prominent field of study in marketing (Tregear, 2003; Ashworth, Schmidt, Pioch \& Hallsworth, 2006; Trunfio, Petruzzellis, \& Nigro, 2006; McKechnie, Grant \& Fahmi, 2007; Parrish, Cassill \& Oxenham, 2004; Cocheo, 2010; Toften \& Hammervoll, 2013), lack of widely accepted theoretical study has made it difficult to operationalize it at practical level despite of its emmese potential (Toften \& Hammervoll, 2013). Due to some similarities between two concepts - segment and niche or sometimes 'small' or 'narrow' market, in most of the cases these two concepts are overlapped or used synonymously which has worked as a barrier for practitioners to unleash the actual potential of niche market (Toften \& Hammervoll, 2013). With such notion, after more than 20 years researchers - Toften and Hammervoll (2013) have come up with the first comprehensive review of niche marketing research and have defined niche marketing as "The process of carving out, protecting and offering a valued product to a narrow part of a market that displays differentiated needs." They have argued that this definition does not ignore the similarities between segment and niche, but surely distinguished it from the fundamental thoughts of segmentation and works as a baseline for the practical application.

\section{Methodology}

This is a conceptual paper developing a conceptual framework and three propositions considering previous research works; where proposed framework is exemplified by a single case study on the company named 'Hövding'. It conducts a systematic literature review (Tranfield, Denyer \& Smart, 2003; Denyer \& Tranfield, 2008; Wang \& Chugh, 2014) within the field of dynamic capabilities, breakthrough innovation and niche market with an aim to understand the impact of dynamic 
capabilities on a startup's innovation in a niche market. A qualitative content analysis has been applied to review 24 articles published in multi-disciplinary peer-reviewed journals (language:English) between 1980 and 2019. Authors have imposed this time frame to ensure widespread coverage of documents within this field of study. Since content analysis as a research method offers researchers new insights along with a condensed and broad description of the phenomenon aiming to build up a conceptual map or categories (Krippendorff, 1980; Elo \& Kyngäs, 2008) , it is appropriate for this study. As part of research process, a descriptive evaluation of selected literatures is carried out based on predefined set of analytic categories (Seuring \& Gold, 2012) like dynamic capabilities and breakthrough or radical innovation, startups or entrepreneurs in a niche market and later on it is followed by the content analysis. It is inductive approach as the research question refers to a phenomenon with fragmented knowledge in that particular field of the study (Elo \& Kyngäs, 2008; Seuring \& Gold, 2012). In order to increase understanding of the phenomenon and to provide more generalized knowledge in the field, authors have interpreted gathered literature following a few steps like coding, categorization and abstraction leading to the conceptual model (Elo \& Kyngäs, 2008).

In this study, at first authors have conducted a systematic literature review (SLR) as summarized in the following flowchart, as it ensures validity of the study by presenting a detailed process, systematically generates relevant arguments closely related to the research question and finally provides generalized result (Wang \& Chugh, 2014). In the beginning of this SLR process (see Figure 1), research objective along with conceptual boundaries (key words: dynamic capabilities and breakthrough innovation, startups in niche market) are set to gather relevant articles. Then based on defined inclusion criteria authors have searched articles in the electronic database: Web of Science. After searching keywords - dynamic capabilities and breakthrough or radical innovation, the result shows 33 articles and then applying exclusion criteria during reading abstract and skimming the body of literature, 16 articles have been selected for further review. Same procedure has been repeated with other keywords - startups/entrepreneur and niche/small market and only 1 article has been selected out of 9. Due to this low number of articles with these keywords, to validate this searching authors have used other databases like One Search and Google scholar which results in 5 closely relevant articles. Moreover, it is revealed that though the researcher David J. Teece has contributed a lot in the field of dynamic capability study $(1997,2007)$, his research works did not come out during the search in the Web of Science database. Therefore, authors have used his name specifically in One Search and Google Scholar to find out relevant literatures.

Figure 1: Adapted from Wang and Chugh (2014), A summary of systematic literature review process.

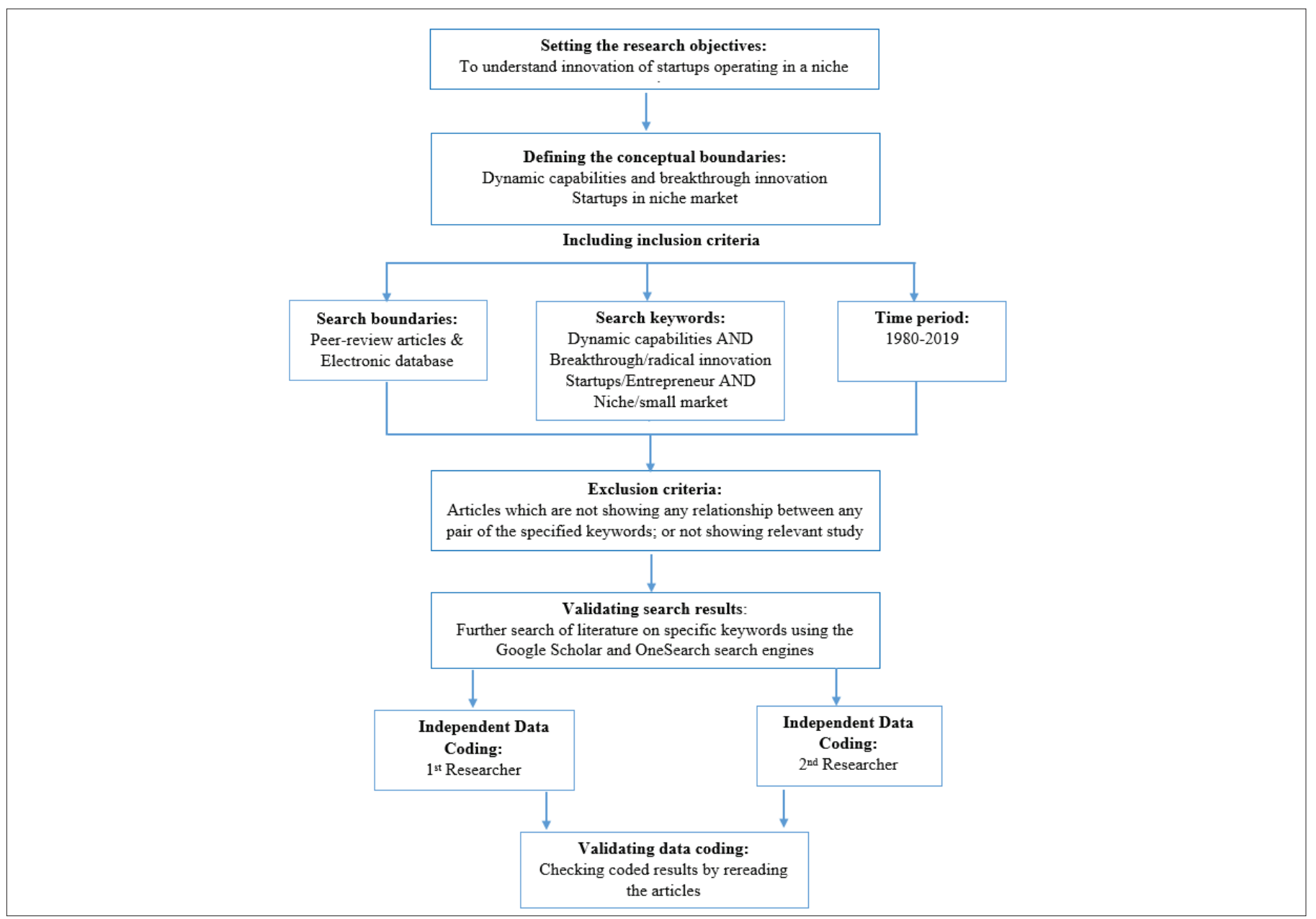

ISSN: 0718-2724. (http://jotmi.org) 
In order to conduct systematic content analysis, at first authors have read articles thoroughly to understand focal research area, then categorized and coded the content of the articles in terms of identification of key terms concerning the phenomenon, research topic, authors, research type and the findings (Aarikka-stenroos et al., 2014). Crosschecking and vigorous discussion among authors have increased the internal validity of the findings; where use of theoretically predefined categories and their specific definitions have enhanced the validity of the coding process (Seuring \& Gold, 2012). Moreover, theory based abstraction of the content analysis resulting to more generalized findings have secured external validity of this study (Elo \& Kyngäs, 2008). Finally, clear documentation of the entire research process and authentic citations of articles have ensured transparency and transferability of this study (Elo \& Kyngäs, 2008; Seuring \& Gold, 2012).
Authors have illustrated the case of the company named 'Hövding' to exemplify the proposed conceptual model. Here authors have used secondary data (from company website, annual report, industry report, authentic industry specific blog, interviews published in Yahoo Finance and LinkedIn) to get in-depth information about the phenomenon in that particular company followed by the 'how' research question (Yin, 2018). Since this Swedish company started its journey as a young startup by winning the Venture Cup - the Nordic business plan competition and succeeded to commercialize its breakthrough innovation in a niche or comparatively very new small market through its more than seven years of operations in the European market (Maack et al., 2011; "Invitation to acquire stocks in Hövding Sweden AB", 2017), it has been considered as a perfect fit for this study. Moreover, from the very beginning it has received collaborative support from different research institutions and organizations operating in EU ("Hövding yearly report", 2017), which has made this case a relevant one.

\section{Content of the reviewed articles}

Table 1: Content of the reviewed articles.

\begin{tabular}{|c|c|c|c|}
\hline Topic & Authors & Research type & Findings \\
\hline $\begin{array}{l}\text { China's and India's transition from } \\
\text { production to innovation }\end{array}$ & $\begin{array}{l}\text { Altenburg, Schmitz \& } \\
\text { Stamm (2007) }\end{array}$ & $\begin{array}{l}\text { Case studies based on } \\
\text { secondary sources }\end{array}$ & $\begin{array}{l}\text { The global distribution of innovation activities has begun to } \\
\text { move eastwards except OECD countries. For China and India } \\
\text { the most important input factor for innovation system is human } \\
\text { capital and significant investment in human resources have } \\
\text { positioned those two countries as global destination for R\&D } \\
\text { outsourcing. }\end{array}$ \\
\hline $\begin{array}{l}\text { The managerial process of innova- } \\
\text { tion funnel for breakthrough inno- } \\
\text { vation }\end{array}$ & $\begin{array}{l}\text { He, Probert \& Phaal } \\
(2008)\end{array}$ & Case study & $\begin{array}{l}\text { Organizations often put a large amount of resources in the front end } \\
\text { of the innovation process funnel, which results in clogged pipeline } \\
\text { rather than breakthrough innovation in the other end. To minimize } \\
\text { this problem, some industry practice has changed innovation pro- } \\
\text { cess model: from planned towards organic models, from user centric } \\
\text { to user lead innovation, from dynamic modeling towards complexity } \\
\text { modeling, from value capturing towards value exchanging. }\end{array}$ \\
\hline $\begin{array}{l}\text { The management of internal } \\
\text { R\&D stakeholders and their invol- } \\
\text { vement dynamics in breakthrough } \\
\text { R\&D projects }\end{array}$ & $\begin{array}{l}\text { Hooge \& Dalmasso } \\
(2015)\end{array}$ & $\begin{array}{l}\text { A longitudinal case study } \\
\text { with mixed method re- } \\
\text { search approach ( } 5 \text { years } \\
\text { time span) }\end{array}$ & $\begin{array}{l}\text { The dynamics of involvement and the legitimacy by the three } \\
\text { distinctive groups of internal R\&D stakeholders: technological } \\
\text { knowers and experts, innovation design strategists, and internal } \\
\text { collaboration strategists play very important role in the success of } \\
\text { company's breakthrough innovation projects. }\end{array}$ \\
\hline $\begin{array}{l}\text { Causality among environmental } \\
\text { uncertainties, strategic orientation, } \\
\text { innovation and performance of } \\
\text { business }\end{array}$ & $\begin{array}{l}\text { Fernandes \& Solimun } \\
(2017)\end{array}$ & Relationship causal studies & $\begin{array}{l}\text { Innovations mediate the impact of environmental uncertainties } \\
\text { on business performance. Highly innovative companies have } \\
\text { long-term sustainable business performance and competitive ad- } \\
\text { vantage. }\end{array}$ \\
\hline $\begin{array}{l}\text { Strategy transformation through } \\
\text { strategic innovation capability }\end{array}$ & $\begin{array}{l}\text { Kodama \& Shibata } \\
(2014)\end{array}$ & $\begin{array}{l}\text { In-depth longitudinal case } \\
\text { study (30 years time span) }\end{array}$ & $\begin{array}{l}\text { In a big corporation, top management puts continuous effort to } \\
\text { form a new development organization within the company to } \\
\text { manage exploration and exploitation processes through the ope- } \\
\text { rations of existing and new organizations; and achieve strategy } \\
\text { transformation securing superior position in the market. }\end{array}$ \\
\hline
\end{tabular}




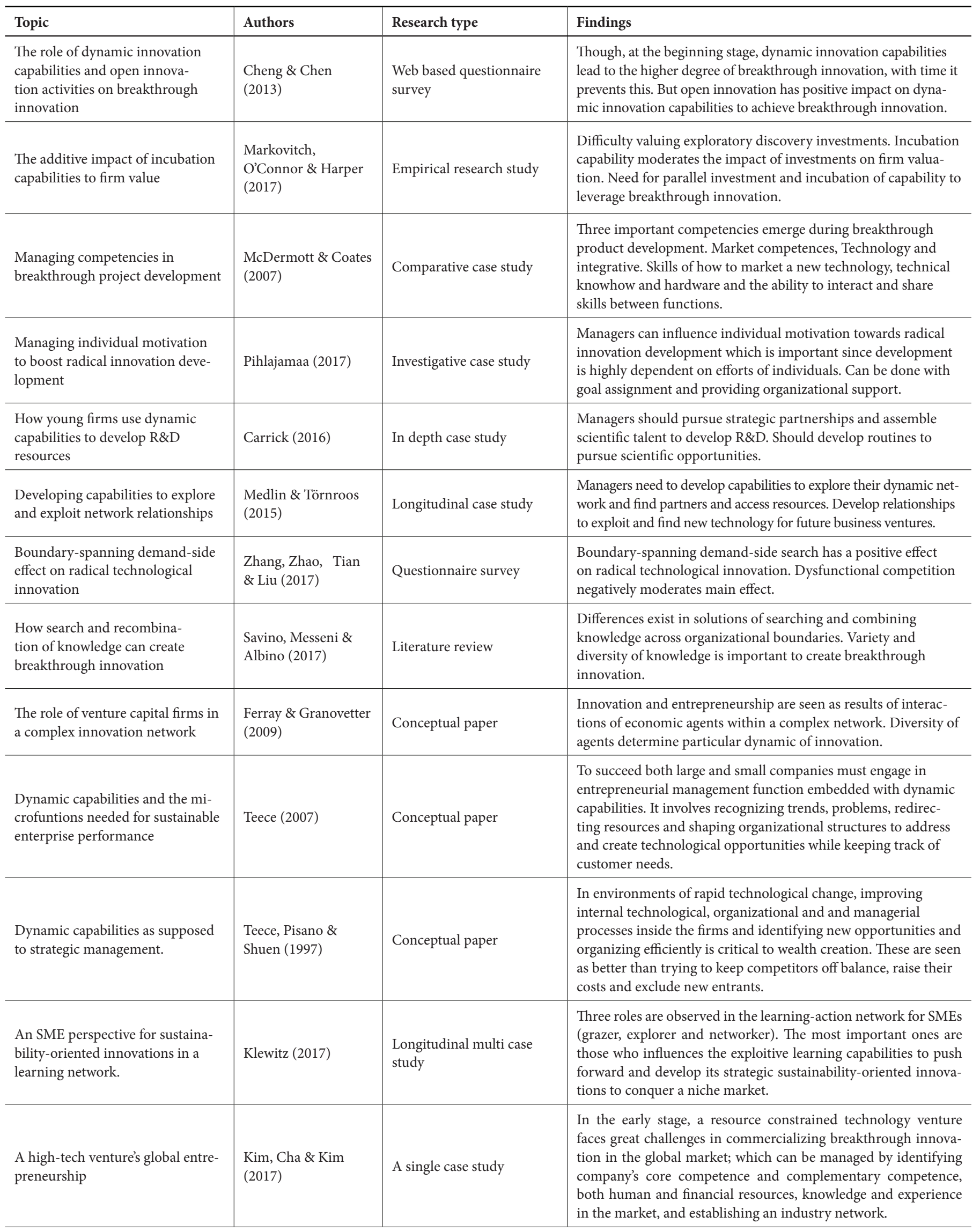




\begin{tabular}{|c|c|c|c|}
\hline Topic & Authors & Research type & Findings \\
\hline $\begin{array}{l}\text { Entrepreneurial resources, dyna- } \\
\text { mic capabilities and start-up per- } \\
\text { formance of high-tech firms }\end{array}$ & Wu (2007) & Questionnaire survey & $\begin{array}{l}\text { In high-tech startups, dynamic capability work as an inter- } \\
\text { mediate variable between startup performance and resources. } \\
\text { Abundant entrepreneurial resources positively influence external } \\
\text { partners' willingness to enter into the cooperative network of the } \\
\text { startup firm and consequently effectiveness of this network en- } \\
\text { hance start-up's dynamic capabilities. }\end{array}$ \\
\hline $\begin{array}{l}\text { The contribution of design and } \\
\text { technological innovation on the } \\
\text { growth of startup companies in the } \\
\text { competitive business environment }\end{array}$ & Moroni et al. (2015) & Literature review & $\begin{array}{l}\text { The strategic management of design and innovation in the orga- } \\
\text { nizational environment of young startups can lead to growth and } \\
\text { greater of acceptance of the product in the market. }\end{array}$ \\
\hline $\begin{array}{l}\text { Innovator firm's networks for the } \\
\text { commercialization of innovation }\end{array}$ & $\begin{array}{l}\text { Aarikka-stenroos et } \\
\text { al. (2014) }\end{array}$ & Literature review & $\begin{array}{l}\text { Successful commercialization of both radical and incremental in- } \\
\text { novation of firm needs support from different actors of divergent } \\
\text { networks such as users, distributors, complementaries, supplier, } \\
\text { investors, associations, public organization, policy makers and } \\
\text { regulators. Here due to the complex network of R\&D for radi- } \\
\text { cal innovation, firms already possess relatively advanced network } \\
\text { capabilities. }\end{array}$ \\
\hline $\begin{array}{l}\text { Niche marketing research: status } \\
\text { and challenges }\end{array}$ & $\begin{array}{l}\text { Toften \& Hammer- } \\
\text { voll (2013) }\end{array}$ & Literature review & $\begin{array}{l}\text { Lack of well accepted theoretical research on niche marketing } \\
\text { concept and its operationalization leads to inadequate research- } \\
\text { oriented recommendations for practitioners to ensure effective } \\
\text { use of it. }\end{array}$ \\
\hline
\end{tabular}

\section{The case: Hövding}

Hövding is a Swedish innovative company selling and developing a bicycle helmet in the form of an airbag around your neck that deploys around your head when in a crash for increased safety and convenience ("Hövding", n.d.). The company was founded in 2006 by two master students from Lund University with inspiration from a law requiring children under 15 to wear a helmet ("Invitation to acquire stocks in Hövding Sweden AB”, 2017). Around 130000 have been sold and are available in approximately 1100 stores around Europe and online on the company website. The company has around 33 employees and are focused on recruiting personnel with specific experience and skills to complement existing knowledge. In 2012 the company hired a now CEO Fredrik Carling to commercialize the company and lead it into the future since the company lacked such knowledge ("Invitation to acquire stocks in Hövding Sweden AB”, 2017). The company has since it launched its first product in 2011 developed an upgrade Hövding 2.0 and are releasing the new improved product Vega in 2019 (“LinkedIn", 2018).

The company has developed a network of different business partners and organizations over the years, such as production partners in Japan who are in charge of producing the airbag and electronics in their factories in China ("Hövding yearly report", 2017). Starting out they hired the Swedish technical research institute to develop a method of testing the product and help them improve the product. They also cooperated with Alva Sweden AB to develop the airbag and tested the device extensively and further development has resulted in lowered production cost for the company enabling them to lower their price.
The development and incremental improvements of the products has resulted in an extensive amount of patents to protect the company's resources ("Hövding yearly report", 2017). Large retailers have taken notice of the company and Hövding signed deals with the German retailer Globetrotter along with other companies. With the launch of their new product they are expanding in England with a strategy that is geographically, and channel divided, looking to take advantage of their app connected new device ("LinkedIn", 2018).

The company has gained fame worldwide and has received a number of different awards for its innovative design ("Hövding yearly report", 2017). When the company launched its product in 2011 they got one of the world's biggest design award; the Index award for their innovative design and have received many since and such as for its inspiring marketing with a Webby award. Their product has also been the subject of research articles published in renowned research papers.

\section{Content analysis and results}

Dynamic capabilities and Breakthrough innovation. Looking at the findings of the reviewed articles (see Table 1) authors find many interesting effects of dynamic capabilities on companies such as performance and their ability to innovate. One such example presented by researchers (Altenburg et al., 2007) was the impact of investing in human capital and the effect it could have on creating innovation. Companies would develop their innovation capabilities by investing in human resources consequently boosting their innovativeness which in turn can increase a company's competitive advantage (Wu, 2007). Some companies choose to outsource these functions to countries like China and India which has made them into R\&D 
powerhouses focusing solely on research for companies. But in these countries, it is also common for local companies looking to go international to acquire personnel from other countries to gain a competitive advantage (Fleury et al., 2013). Fleury expresses that the main reason for doing this is the fact that the local environment is not supportive enough and does not offer the same benefits as operating in more developed countries for developing innovation capabilities. In his words: "Country of origin effects on firms' innovation capability" (Fleury et al., 2013).

Regarding breakthrough innovation researchers have expressed the important role different groups' play when working on R\&D (Hooge \& Dalmasso, 2015). They mean that these groups in particular are experts and people with technical knowledge as well as innovation design strategists and people in charge of internal collaboration. The involvement of these groups are paramount to the success of breakthrough innovation projects. Much like these groups are important so are other important competencies as put forth by McDermott and Coates (2007) in their case study. They mention that market competences, technology and integrative skills are important capabilities for knowing how to sell products and especially for sharing knowledge between functions to boost breakthrough product development. These are important but researchers have also found that companies that put a lot of resources in the beginning of the process of development can result in it all backing up and getting clogged (He et al., 2008). As researchers state (He et al., 2008)

Despite the large amount of resources and talents that organisations pour into the front end of the innovation funnel, few breakthrough innovations emerge at the other end. The pipelines often clog with inconsequential opportunities, ideas and projects while potentially slowing the valuable ones during their passage. Therefore, the funneling capabilities are compromised, and the funnel becomes a tunnel. (p.368).

This hinders the development of breakthrough innovation and so companies are changing their tactics adopting more organic innovation models and going for value exchanging instead of value capturing.

As presented by many researchers, dynamic capabilities can boost and lead to breakthrough innovation for companies but according to Cheng and Chen (2013) it can also have significant consequences. They noted that companies with developed and distinctive capabilities tended to get rooted and ran the risk of missing out on new trends and changes in the external environment. Teece (2007) emphasizes the importance of recognizing trends and problems the company might have. He urges companies in rapid technological changing environments to engage in entrepreneurial management and improving management processes by developing specific dynamic capabilities. He puts it like this: "It is a new hybrid: entrepreneurial managerial capitalism. It involves recognizing problems and trends, directing (and redirecting) resources, and reshaping organizational structures and systems so that they create and address technological opportunities while staying in alignment with customer needs" (p. 1346-1347).
These are meant to keep companies observant of technical opportunities and avoid the danger of becoming rooted. Kusunoki (1997) also illustrates in his article how companies can become stuck as tech heavy companies and especially market leaders emphasizes their primary technological capabilities and fail to capitalize on new ones. This may prevent them from creating breakthrough innovation projects and another way to solve this was presented by Pihlajamaa (2017) in his article. He points out that managers have the power to influence personals individual motivation towards breakthrough innovation development. This can be very important as companies rely on their staff for new innovative ideas and organizational support can therefore play a big role.

Internal resources like staff is important but external competencies can be just as important as Carrick (2016) points out and encourages managers to pursue strategic partnerships with the purpose of acquiring talent to develop R\&D to pursue opportunities. Medlin and Törnroos (2015) much like Carrick encourages managers to pursue external partnerships but also develop capabilities to explore their networks and acquire resources. Managers need to find relationships to exploit to be able to find new technologies for future projects. Researchers have found that there are a lot of differences in the way companies search and combine knowledge in every industry (Savino et al., 2017). They stress the fact that variety and diversity of knowledge is important for the creation of breakthrough innovation and that managers should find different ways of sourcing that knowledge. One way of sourcing new knowledge was presented by Ferray and Granovetter (2009) mean that innovation is the result of interactions between economic agents of companies. Here diversity comes into play again as a diversity of agents help foster innovation in different ways. Companies however have had problems valuing their efforts when it comes to exploratory discovery investments (Markovitch et al., 2017). They encourage companies to develop incubations capabilities parallel to investments to leverage breakthrough innovation development projects.

Bigger organizations have been found to put effort into trying to create development organizations within the existing one, trying to get the most out of exploring and exploiting resources through new and existing organizations (Kodama \& Shibata, 2014). Researchers saw that firms using boundary-spanning search when looking for new demands were more efficient in their development of technical radical innovation development (Zhang et al., 2017). It was also found that companies tend to run into trouble in early stage commercialization of their breakthrough products (Kim et al,. 2017). This concerned firms with resource restrictions and it was shown that this could be managed by identifying core competencies such as human capital and complementary resources together with experience in the market to establish networks.

Niche market and startups. Authors have found very few articles focusing on the operation of startups in a niche market or the entrepreneurs at the early stage in a small market. There are three empirical studies on startups among which two are within the context of hightech industry (Klewitz, 2017; Kim et al., 2017; Wu, 2007), two concep- 
tual papers on the performance and operational challenges of startups (Moroni et al., 2015; Aarikka-stenroos et al., 2014) and another one focusing on inadequate research on niche marketing concept and its potential in research field (Toften \& Hammervoll, 2012).

According to Kim et al. (2017), when a high-tech startup expand its business operation into another country, it very crucial for it to figure out its core and complementary competencies; which is also echoed in research work by $\mathrm{Wu}$ (2007). Here core competency is its innovative product and complementary competencies include knowledge and experience in new market in terms of customer needs and economy, investable resources and time for market development and finally established industry network (Kim et al., 2017). Researchers have argued that as new startups have limited human and financial resources, it could pioneer its business in a new market before its competitor through strong global partnerships. While talking about young startup's resources, Wu (2007) has pointed out that dynamic capabilities of a startup plays an important role to transform entrepreneurial resources into performance, especially in a technology intensive dynamic market. To be successful in a fast paced market, small resource constrained startups have to gain complementary resources from external sources (Wu, 2007; Kim et al., 2017; Klewitz, 2017). Because according to $\mathrm{Wu}(2007)$ :

Often, a start-up cannot thrive on the entrepreneur's human and financial capital alone. Significant other resources must also be in place to produce success. Therefore, the entrepreneur's networks (whether personal and relation-based networks or strategic alliances) are crucial for acquiring the requisite complementary resources and capabilities. (p. 550)

Since new startups are small in size and have high rate of failure, it is very challenging to attract supportive allies or corporations in its network ( $\mathrm{Wu}, 2007)$. Here researcher stated that balanced reciprocity can help in building this network, that is the more internal entrepreneurial resources are, the greater positive influence on external partners for entering into this cooperative network and consequently effectiveness of this network enhances start-up's dynamic capabilities. The growth of a startup in a niche market largely depends upon either on its design-driven innovation or breakthrough innovation (Moroni et al., 2015). Researchers argue that breakthrough innovation can attract consumers immediately due to its immense creativity. But for successful commercialization of both incremental and breakthrough innovation, startups have to rely on different actors of divergent networks comprised of users, distributors, complementariness, supplier, investors, associations, public organizations, policy makers and regulators (Aarikka-stenroos et al., 2014). Here radical or breakthrough innovation enjoys privileged positions, as firms possess relatively advanced networking capabilities due to the complex network of R\&D for this type of innovation. This is a positive finding for the startup with breakthrough or radical innovation. Though researchers have highlighted niche marketing as a great opportunity for a startup to commercialize its innovative ideas (Moroni et al., 2015), it lacks structured in-depth study to give practitioners a clear guideline on niche marketing (Toften \& Hammervoll, 2013). Toften and Hammervoll (2013) argue that despite of its immense potential, researchers have ignored this field of study for more than 20 years. Based on review of previous research works, they have proposed a new definition which has been placed in the literature review part of this study as a base for the term 'niche market'. They have also stated, "successful niche marketing appears to require the use of specialization, relationship marketing, developing internal dynamic capabilities and building protective barriers" (Toften \& Hammervoll, 2013). They have considered technology intensive high-quality product, long-term customer relationships, patents, certifications from other organizations, and high credibility/valued as specialists by customers.

Research gap. Going through and analyzing the reviewed articles it can observed that a lack of research regarding startups in a niche market and the effects dynamic capabilities can have to generate breakthrough innovation exists. Following the content analysis, it is revealed that though those categories like 'dynamic capabilities, breakthrough innovation' and 'startups in niche market' have been studied at different dimensions within different context, theoretical knowledge in these field is quite fragmented. Moreover, empirical works are to some extent disjointed to establish relationship among those categories. Researchers have discussed that targeting niche market is a good option for startups (Moroni et al., 2015), but at the root level researchers are yet to be in an agreement to define niche market concept without overlapping it with segmentation (Toften \& Hammervoll, 2013). Thus, it lacks clear guideline for practitioners who wants to enter into a niche market with a breakthrough idea. Regarding dynamic capabilities researchers have focused mostly on their role in creating breakthrough innovation and how managers can reorganize and manage these whilst creating extensive partnerships to acquire specialized knowledge (Fleury et al., 2013; Medlin \& Törnroos, 2015; Ferray \& Granovetter, 2009; Teece, 2007). Though a group of researchers are focusing on dynamic capabilities and breakthrough innovation of a startup as sources of success (Wu, 2007; Kim et al., 2017; Klewitz, 2017), theoretical studies are not enough to foresee diffusion of its dynamic capabilities within a niche market context. More specifically the relationship between startup's dynamic capabilities, breakthrough innovation and niche market is in quite a blur to make it concrete.

\section{Propositions, model and Conclusion}

Propositions and case examples. After reviewing the chosen articles three propositions have been developed following our observations and are exemplified with the use of the Hövding case presented earlier.

\section{P1: Dynamic capabilities of a startup work as a foundation for a startup to develop breakthrough innovation.}

For many companies having different kinds of dynamic capabilities is an important part for developing breakthrough innovation and this can also be said for Hövding. Hövding was founded by two students possessing technological knowledge and design as they had both gone through a masters program regarding those subjects. To continue developing their technological capabilities the company hired 
more people as time progressed to work on innovative new projects which helped them launch their first product and has led to upgrades and the soon to be released Vega helmet. It proved to be important for the company to invest in these technological capabilities and without them the company might not have been able to develop their first prototype. This illustrates the importance for startups to invest in dynamic capabilities early which in Hövdings case meant their technological development team to develop breakthrough innovations and succeed in the market.

P2: Core competency and industry network as part of dynamic capabilities is crucial to scaleup in a niche market.

The company had developed their technological capabilities but needed marketing capabilities and experience to commercialize their product and did so by hiring a CEO and staff to gain relevant knowledge. This proved beneficial as sales grew over time with the proper knowledge to generate them now acquired. The company soon started networking and started working with a Japanese company to develop and produce the airbag and electronics for their product. Hövding has with this and other strategic connections been able to lower their price as a result of more efficient production and development consequently selling more which has allowed them to grow. To develop the airbag, they cooperated with the Swedish technical research institute to develop testing methods and with Alva Sweden to go on and create the actual airbag. Hövding again shows us the importance of dynamic capabilities and how networking can lead to further development of their breakthrough capabilities as a startup breaking into a niche market. Their innovation capabilities and other core competencies have been the driving force for Hövding and networking with suppliers and institutes has been critical for their progress.

P3: Breakthrough innovation works as a way to acquire customer acceptance and foothold in a niche market.

Hövding broke into a niche market focusing on people riding bikes and wishing to protect themselves without using the traditional oldfashioned option. Designers of this invisible bicycle helmet figured out people's latent demands and expectations of the helmet through consumer surveys and discovered that they wanted to wear a helmet without ruining their hairstyle. This worked as an inspiration behind the breakthrough design of this airbag helmet ("Hövding yearly report", 2017). The helmet market had a lot of competition but with their breakthrough design they managed to distinguish themselves from the competition by being a very different option to the same old alternatives. Their innovative product got a lot of positive attention for thinking outside the box and solving a problem in a way no one else had managed to do before. This innovativeness allowed them to gain market acceptance resulting in rising sales numbers that are steadily getting higher every year and has gained them a firm position in a niche market.

Model. With these propositions authors propose following conceptual model (see Figure 2) showing the possible linkages between each factor to encourage studies investigating these connections.
Figure 2: Proposed model for linkages between factors influencing startup performance in niche market

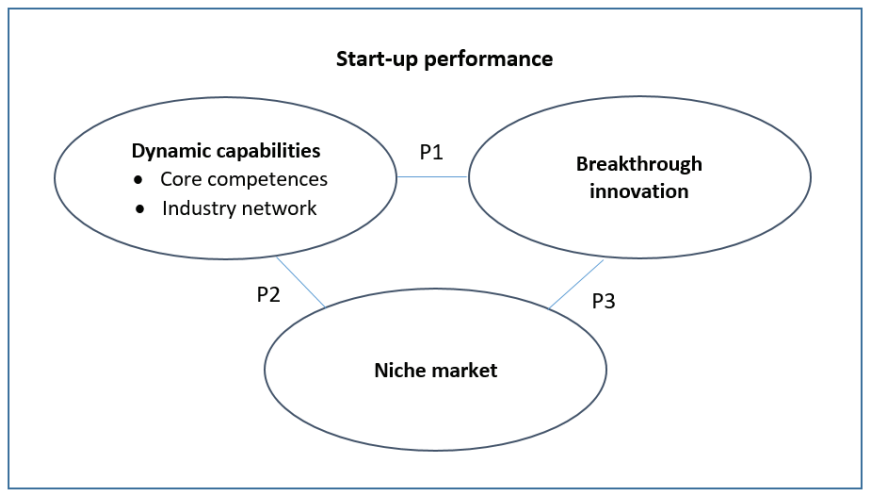

Conclusion. In conclusion the authors of this paper wish to showcase through reviewing the current literature that a research gap exists regarding startups in a niche market with dynamic capabilities and breakthrough innovations as a source of success. These subjects have been studied separately but not together to help understand the operation of startups in a niche market and to what extent dynamic capabilities impact a firm's development of breakthrough innovation. The authors of this paper therefore recommend further study on this particular subject to further add to the wealth of knowledge about the importance of dynamic capabilities and breakthrough innovation and especially for startups operating in a niche market.

\section{Limitations, managerial implications and further studies}

Limitation. Flexible and non-linear nature of content analysis method has made it challenging for the researchers to manage huge pile of information within a short time-period (Elo \& Kyngäs, 2007). Following other researchers using this method, authors of this paper have also went through the moment of 'paralysing' to getting started (Sandelowski, 1995) and reading 24 research articles as many times as possible to apprehend essential features without any misinterpretation. Here, purpose of the study has worked as an anchor to carry out this analysis in the most appropriate way possible.

During this study, authors have preferred to use keywords to search articles in the Web of Science database to avoid biases or overrepresentation of particular author/s' works (Seuring \& Gold, 2012). But due to an unknown reason a renowned researcher named David J. Teece's work in dynamic capability did not show up during that search; which has made authors to search his relevant works by using name instead of keywords. Since detail research process has been documented, replicating this work in another similar context will make future researchers to consider this fact.

Managerial implications. This conceptual paper intends to depict relationship between dynamic capabilities, breakthrough innovation and niche market which plays significant role in a startup's performance. As previous scholarly works are very much focused on the big corporation's innovation process and entrepreneurial orientation, 
startup's performance in a niche market is found to be less explored (Moroni et al., 2015; Toften \& Hammervoll, 2013). In such circumstance, this conceptual paper with a conceptual model and propositions will influence academic researcher pay attention on this field from different perspective. Further research in terms of applying this developed model will contribute to enrich existing research field and consequently it has potential to give an updated view in the course content of innovation and entrepreneurship offered at different educational institutes.

Since in Scandinavian countries like Sweden, young startups are encouraged to take active part in the economic development with their breakthrough ideas through business plan competitions, training institutes and research centers (Maack et al., 2011), any practice oriented new insight in this field will enhance young startup's learning process. Developed propositions and the model in this paper give training and research centers an option to verify this new understanding with real practitioners through trial and error; and upgrade existing learning materials.

Further research studies. For future research the authors recommend a multiple case study with in-depth interviews with staff at startup companies or those who have made it through the startup period successfully so they can be examples of what to do. It would be good to talk with people in management to get an overview of the operation. Even better would it be if researchers could get interviews with founders of the companies as it would be interesting to find out specifically what kind of competencies they possessed when starting the company and what made them succeed. Considering Toften's and Hammervoll's (2013) statements regarding the lack of clear definition of niche market as a guideline for practitioners, makes this type of research even more important since it has been largely ignored to over 20 years.

\section{Reference list}

Aarikka-Stenroos, L., Sandberg, B., \& Lehtimäki, T. (2014). Networks for the commercialization of innovations: A review of how divergent network actors contribute. Industrial Marketing Management, 43(3), 365-381.

Altenburg, T., Schmitz, H., \& Stamm, A. (2008). Breakthrough? China's and India's transition from production to innovation. World development, 36(2),325-344.

Antikainen, M. J., \& Väätäjä, H. K. (2010). Rewarding in open innovation communities-how to motivate members. International Journal of Entrepreneurship and Innovation Management, 11(4), 440-456.

Ashworth, C.J., Schmidt, R.A., Pioch, E.A., \& Hallsworth, A. (2006). Web-weaving: an approach to sustainable e-retail and online advantage in lingerie fashion marketing. International Journal of Retail \& Distribution Management, 34(6),497-511.

Arenius, P., \& Minniti, M. (2005). Perceptual Variables and Nascent Entrepreneurship. Small Business Economics, 24(3), 233-247.
Benner, M. J., \& Tushman, M. L. (2003). Exploitation, exploration, and process management: The productivity dilemma revisited. Academy of management review, 28(2),238-256.

Blank, S.G., \& Dorf, B. (2012). The startup owner's manual. Vol. 1 : the step-by-step guide for building a great company.California, USA: K\&S Ranch.

Bosma, N., \& Schutjens, V. (2009). Mapping entrepreneurial activity and entrepreneurial attitudes in European regions. International Journal of Entrepreneurship and Small Business, 7(2), 191-213.

Carrick, J. (2016). R\&D resources development in life sciences ventures: a dynamic capabilities perspective. Journal of Small Business and Enterprise Development, 23(4), 1191-1207.

Cheng, C.C., \& Chen, J.S. (2013). Breakthrough innovation: the roles of dynamic innovation capabilities and open innovation activities. Journal of Business \& Industrial Marketing,28(5), 444-454.

Cocheo, S. (2010). Niche in your future?. American Bankers Association, ABA Banking Journal, 102(10),16-22.

Cruz-Ros, S., Garzón, D., \& Mas-Tur, A. (2017). Entrepreneurial competencies and motivations to enhance marketing innovation in Europe. Psychology \& Marketing, 34(11),1031-1038.

Davenport, T., Leibold, M., \& Voelpel, S. (2006). Strategic Management in the Innovation Economy. Strategy Approaches and Tools for Dynamic Innovation Capabilities. New York, NY: Wiley.

Deeds, D. L., DeCarolis, D., \& Coombs, J. (2000). Dynamic capabilities and new product development in high technology ventures: An empirical analysis of new biotechnology firms. Journal of Business venturing, 15(3), 211-229.

Denyer, D. , \& Tranfield, D. (2008). Producing a systematic review. In Buchanan, D. (Ed.), The Sage Handbook of Organizational Research Methods (pp.671-689). London, UK: Sage.

De Visser, M., de Weerd-Nederhof, P., Faems, D, Song, M., Van Looy, B., \& Visscher, K. (2010). Structural ambidexterity in NPD processes: a firm-level assessment of the impact of differentiated structures on innovation performance. Technovation, 30(5/6), 291-299.

Drucker, P. F. (1985). Innovation and Entrepreneurship: Practice and Principles. New York: HarperBusiness.

Elo, S., \& Kyngäs, H. (2008). The qualitative content analysis process. Journal of advanced nursing, 62(1), 107-115.

Eisenhardt, K. M., \& Martin, J. A. (2000). Dynamic capabilities: what are they?. Strategic management journal, 21(10-11),1105-1121.

Eurostat. (2017). Eurostat - statistics explained - Innovation statistics. Retrieved from https://ec.europa.eu/eurostat/statistics-explained/index.php?title=Innovation_statistics. 
European innovation scoreboard. (2018). European innovation scoreboard. Retrieved from available at: https://ec.europa.eu/growth/ industry/innovation/facts-figures/scoreboards_en.

Evald, M. R., Klyver, K., \& Christensen, P. R. (2011). The effect of human capital, social capital, and perceptual values on nascent entrepreneurs' export intentions. Journal of International Entrepreneurship, 9(1),1-19.

Ferrary, M., \& Granovetter, M. (2009). The role of venture capital firms in Silicon Valley's complex innovation network. Economy and society, 38(2),326-359.

Fleury, A., Fleury, M.T.L., \& Borini, F.M. (2013). The Brazilian multinationals' approaches to innovation. Journal of International Management, 19(3), 260-275.

Fernandes, A. A. R., \& Solimun. (2017). The mediating effect of strategic orientation and innovations on the effect of environmental uncertainties on the performance of business in the Indonesian aviation industry. International Journal of Law and Management, 59(6), pp.1269-1278.

Gallagher, K. (2011). Secret of the Niche. Global Cosmetic Industry, 179(5), 46

Garcia, R., \& Calantone, R. (2002). A critical look at technological innovation typology and innovativeness terminology: a literature review. The Journal of Product Innovation Management, 19(2), 110-132.

Geels, F. W., \& Schot, J. (2007). Typology of sociotechnical transition pathways. Research Policy, 36, 399-417.

Helfat, C. E., \& Raubitschek, R. S. (2000). Product sequencing: coevolution of knowledge, capabilities and products. Strategic management journal, 21(10-11), 961-979.

He, X., Probert, D. R., \& Phaal, R. (2008). Funnel or tunnel? A tough journey for breakthrough innovations. In 2008 th IEEE International Conference on Management of Innovation and Technology (pp.368373). IEEE.

Henderson, R., \& Cockburn, I. (1994). Measuring Competence? Exploring Firm Effects in Pharmaceutical Research. Strategic Management Journal, 15(S1),63-84.

Hessels, J., Van Gelderen, M., \& Thurik, R. (2008). Entrepreneurial aspirations, motivations, and their drivers. Small Business Economics, 31(3),323-339.

Hockerts, K., \& Wüstenhagen, R. (2010). Greening Goliaths versus emerging Davids - Theorizing about the role of incumbents and new entrants in sustainable entrepreneurship. Journal of Business Venturing, 25(5),481-492.
Hooge, S., \& Dalmasso, C. (2015). Breakthrough R\&D stakeholders: The challenges of legitimacy in highly uncertain projects. Project $\mathrm{Ma}$ nagement Journal, 46(6), 54-73.

Hövding. (n.d.). Test: Hövdings Airbag 8x Safer than a bicycle helmet! This is how it works. Retrieved March 19, 2020, from https://hovding. se/sa-funkar-hovding/?gclid=EAIaIQobChMIw73rnLSU4QIVx8my Ch29OwYSEAAYASABEgKZu_D_BwE.

Hövding yearly report. (2017). Hövding Financial Information 2017. Retrieved March 19, 2020, from http://ir.hovding.se/phoenix. zhtml?c=254018\&p=irol-reportsannual.

Invitation to acquire stocks in Hövding Sweden AB. (2017). Prospekt Hövding. Retrieved March 19, 2020, from https://finansinspektionen.se/en/our-registers/prospektregistret/GetFile/ ? id $=0$ b 47 bae 5 -a a $72-407$ f -8742 c535c90e300c\&format $=$ application/pdf\&name $=\mathrm{E}: \% 5 \mathrm{CProspekt}$ Publicering\%5CH\%C3\%B6vding\%20556708-0303.pdf.

Johannessen, J. A., Olsen, B., \& Lumpkin, G. T. (2001). Innovation as newness: what is new, how new, and new to whom?. European Journal of innovation management, 4(1), 20-31.

Kim, Y. C., Cha, H., \& Kim, T. (2017). Ahkera Smart Tech: A HighTech Venture's Global Entrepreneurship in Asia. Asian Case Research Journal, 21(2), 311-346.

Klewitz, J. (2017). Grazing, exploring and networking for sustainability-oriented innovations in learning-action networks: an SME perspective. Innovation: The European Journal of Social Science Research, 30(4),476-503.

Krippendorff, K. (1980). Content Analysis: An Introduction to its Methodology. Newbury Park, USA: Sage Publications.

Kodama, M., \& Shibata, T. (2014). Strategy transformation through strategic innovation capability-a case study of Fanuc. R\&D Management, 44(1),75-103.

Kusunoki, K. (1997). Incapability of technological capability: a case study on product innovation in the Japanese facsimile machine industry. Journal of Product Innovation Management, 14(5), 368-382.

Lavie, D., \& Rosenkopf, L. (2006). Balancing exploration and exploitation in alliance formation. Academy of Management Journal, 49(4),797-818.

Lewrick, M., Raeside, R., \& Sailer, K. (2010). Education for entrepreneurship and innovation: Management capabilities for sustainable growth and success. World Journal of Entrepreneurship, Management and Sustainable Development, 6(1/2), 1-18. 
LinkedIn. (2018). Hövding Sverige AB on Linkedin: Doubled sales for Hövding during second quarter 2018. See our CEO Fredrik Carling talk about the report! Retrieved March 19, 2020, from https://www.linkedin.com/feed/update/urn:li:activity:6432497984184815616?fbclid= IwAR3sbhiVAH-A5aPP8pgW7XSh6r_yydPVkU4itoZHT1rltUFokwiwPFOSfr (accessed 19 March 2019).

Maack, K., Klofsten, M., \& Hedner, T. (2011). Venture Cup- the Nordic business plan competition. World Sustainable Development Outlook, 221-241.

Markovitch, D. G., O’Connor, G. C., \& Harper, P. J. (2017). Beyond invention: the additive impact of incubation capabilities to firm value. R\&D Management, 47(3),352-367.

McDermott, C., \& Coates, T. (2007). Managing competencies in breakthrough product development: A comparative study of two material processing projects. IEEE Transactions on Engineering Management, 54(2), 340-350.

McKechnie, D.S., Grant, J., \& Fahmi, M. (2007). Carving a niche for the no-frills carrier, Air Arabia, in oil-rich skies. Journal of Air Transportation, 12 (1),53-66.

Medlin, C. J., \& Törnroos, J. Å. (2015). Exploring and exploiting network relationships to commercialize technology: A biofuel case. Industrial Marketing Management, 49, 42-52.

Moroni, I., Arruda, A., \& Araujo, K. (2015). The design and technological innovation: how to understand the growth of startups companies in competitive business environment. Procedia Manufacturing, 3,2199-2204.

O'Connor, G.C., \& DeMartino, R. (2006). Organizing for Radical Innovation: An Exploratory Study of the Structural Aspects of RI Management Systems in Large Established Firms. Journal of Product Innovation Management, 23(6),475-497.

Parrish, E.D., Cassill, N.L., \& Oxenham, W. (2004). Opportunities in the international textile and apparel marketplace for niche markets. Journal of Fashion Marketing and Management, 8(1), 41-57.

Pihlajamaa, M. (2017). Going the extra mile: Managing individual motivation in radical innovation development. Journal of Engineering and Technology Management,43,48-66.

Ries, E. (2011). The lean startup: How today's entrepreneurs use continuous innovation to create radically successful businesses. Crown Books.

Rogers, E. (2003). Diffusion of Innovations (5th ed.). New York, NY: The Free Press.

Ruiz, J., Soriano, D. R., \& Coduras, A. (2016). Challenges in measuring readiness for entrepreneurship. Management Decision, 54(5),1022-1046.
Savino, T., Messeni Petruzzelli, A., \& Albino, V. (2017). Search and recombination process to innovate: a review of the empirical evidence and a research agenda. International Journal of Management Reviews, 19 (1),54-75.

Sandelowski, M. (1995). Qualitative analysis: what it is and how to begin?. Research in Nursing \& Health, 18, 371-375.

ScaleIt. (2018). Top Scaleups Showcase. Retrieved January 29, 2020 from http://scaleit.biz/

Seuring, S., \& Gold, S. (2012). Conducting content-analysis based literature reviews in supply chain management. Supply Chain Management: An International Journal, 17 (5),544-555.

Song, M., \& Di Benedetto, A. (2008). Supplier's involvement and success of radical new product development in new ventures. Journal of Operations Management, 26(1),1-22.

Schaltegger, S., Hansen, E. G., \& Lüdeke-Freund, F. (2016). Business models for sustainability: Origins, present research, and future avenues. Organization \& Environment, 29 (3), 264-289.

Schoenmakers, W., \& Duysters, G. (2010). The technological origins of radical inventions. Research Policy, 39 (8), 1051-59.

Snow, C. C. (2007). Innovation. Strategic Entrepreneurship Journal,1 (2),101-102.

Sweden. (2019). Innovation in Sweden. Retrieved January 29, 2020 from https://sweden.se/business/innovation-in-sweden

Teece, D. J., Pisano, G., \& Shuen, A. (1997). Dynamic capabilities and strategic management. Strategic management journal, 18 (7), 509-533.

Teece, D. J. (2007). Explicating dynamic capabilities: the nature and microfoundations of (sustainable) enterprise performance. Strategic management journal, 28 (13),1319-1350.

Toften, K., \& Hammervoll, T. (2013). Niche marketing research: status and challenges. Marketing Intelligence \& Planning, 31 (3),272-285.

Tranfield, D., Denyer, D., \& Smart, P. (2003). Towards a methodology for developing evidence-informed management knowledge by means of systematic review. British Journal of Management, 14, 207-222.

Tregear, A. (2003). Market orientation and the craftsperson. European Journal of Marketing, 37 (11/12),1621-1635.

Trunfio, M., Petruzzellis, L., \& Nigro, C. (2006). Tour operators and alternative tourism in Italy: exploiting niche markets to increase international competitiveness. International Journal of Contemporary Hospitality Management, 18(5),426-438.

Wang, C.L., \& Chugh, H. (2014). Entrepreneurial Learning: Past Research and Future Challenges. International Journal of Management Reviews, 16(1),24-61. 
Wu, L.Y. (2007). Entrepreneurial resources, dynamic capabilities and start-up performance of Taiwan's high-tech firms. Journal of Business research, 60(5),549-555.

Yin, R.K. (2018). Case study research and applications: Design and methods. Thousand Oaks, California: Sage publications.
Zhang, W. Zhao, Y, Tian, L., \& Liu, D. (2017). Boundary-spanning demand-side search and radical technological innovations in China: The moderation of innovation appropriability. Management Decision, 55(8),1749-1769.

Zollo, M., \& Winter, S. G. (2002). Deliberate learning and the evolution of dynamic capabilities. Organization Science, 13(3),339-351. 